\title{
Improving the catalytic effect of peroxodisulfate and peroxodiphosphate electrochemically generated at diamond electrode by activation with light irradiation
}

\author{
Danyelle Medeiros de Araújo a, Cristina Sáez ${ }^{\text {b }}$, Pablo Cañizares ${ }^{\text {b }}$, \\ Manuel Andrés Rodrigo ${ }^{\mathrm{b}}$, Carlos A. Martínez-Huitle ${ }^{\mathrm{c}, \mathrm{d}, *}$ \\ ${ }^{a}$ Federal Institute of Education, Science and Technology of Rio Grande do Norte, Povoado Base Física, Zona Rural, CEP 59508-0, Ipanguaçu, RN, Brazil \\ ${ }^{\mathrm{b}}$ Department of Chemical Engineering, Universidad de Castilla-La Mancha, Campus Universitario s/n, 13071, Ciudad Real, Spain \\ c Institute of Chemistry, Federal University of Rio Grande do Norte, Lagoa Nova CEP, 59078-970, Natal, RN, Brazil \\ ${ }^{\mathrm{d}}$ National Institute for Alternative Technologies of Detection, Toxicological Evaluation and Removal of Micropollutants and Radioactives (INCT-DATREM), \\ Institute of Chemistry, Unesp, P.O. Box 355, 14800-900, Araraquara, SP, Brazil
}

\section{H I G H L I G H T S}

- Light irradiation promotes an enhancement on the oxidative power of oxidants.

- RhB is oxidized by the oxidants produced electrolytically during the electrolysis.

- Photoelectrolysis approach is more efficient than electrolysis.

- Peroxodisulfate is activated by UV light being more efficient than peroxophosphate.

- Synergic effects are attained when electrogenerated oxidants are UV light-activated.

\section{A R T I C L E I N F O}

\section{Article history:}

Received 1 February 2018

Accepted 19 May 2018

Available online 21 May 2018

\section{Keywords:}

Electrolysis

Photoelectrolysis

Peroxosalts

Rhodamine B

Boron doped diamond
G R A P H I C A L A B S T R A C T

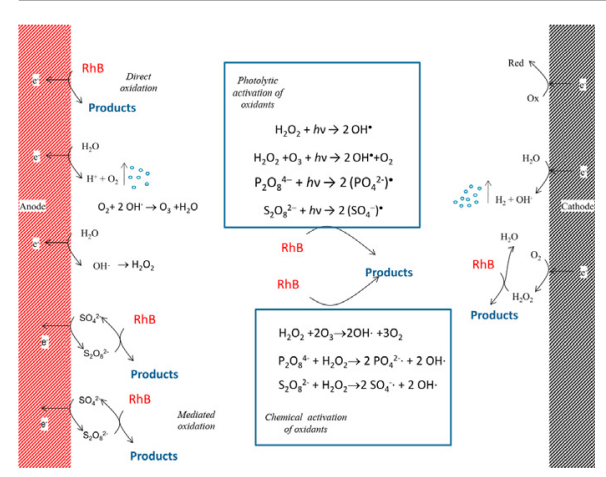

\begin{abstract}
A B S T R A C T
Boron doped diamond (BDD) anode has been used to oxidatively remove Rhodamine $\mathrm{B}$ (RhB), as persistent organic pollutant, from synthetic wastewater by electrolysis, photoelectrolysis and chemical oxidation containing sulfate and phosphate as supporting electrolytes. RhB is effectively oxidized by electrolysis and by chemical oxidation with the oxidants separately produced by electrolyzing sulfate or phosphate solutions (peroxodisulfate and peroxodiphosphate, respectively). The results showed that light irradiation improved the electrolysis of $\mathrm{RhB}$ due to the activation of oxidants under irradiation at high current densities. Meanwhile, the efficiency of the chemical oxidation approach by ex situ electrochemical production of oxidants was not efficient to degrade RhB.
\end{abstract}

(C) 2018 Elsevier Ltd. All rights reserved.

\footnotetext{
* Corresponding author. National Institute for Alternative Technologies of Detection, Toxicological Evaluation and Removal of Micropollutants and Radioactives (INCT-DATREM), Institute of Chemistry, Unesp, P.O. Box 355, 14800-900, Araraquara, SP, Brazil

E-mail address: carlosmh@quimica.ufrn.br (C.A. Martínez-Huitle).
}

\section{Introduction}

In the last decades, the applicability of electrochemical technologies for the environment protection has received great attention. Among these approaches, electrochemical oxidation (EO) is 
the most used, and the recent studies have evidenced the importance of the development of new electrode materials as well as the combination with other technologies, in irder to intensify its efficiency (Bebelis et al., 2013; Sirés et al., 2014). In the former, the introduction of conductive diamond coatings was a significant scientific contribution in the EO (Rodrigo et al., 2001; Polcaro et al., 2004, 2005; Panizza and Cerisola, 2005, 2009; Martinez-Huitle and Ferro, 2006; Sanchez-Carretero et al., 2011; Scialdone et al., 2012; Sires and Brillas, 2012; Borras et al., 2013; Panizza and MartinezHuitle, 2013; Brillas and Martínez-Huitle, 2015; Martínez-Huitle et al., 2015) due to its chemical and electrochemical stability as well as the efficient use of the electricity. Diamond coatings are considered as "non-active" anodes (Panizza and Cerisola, 2009; Sanchez-Carretero et al., 2011; Scialdone et al., 2012; Borras et al., 2013; Panizza and Martinez-Huitle, 2013; Brillas and MartínezHuitle, 2015; Martínez-Huitle et al., 2015) during EO process. The superiority on the oxidative character of diamond anodes in this classification is related to the enthalpy of adsorption of oxidant mediators generated by the water discharge, the hydroxyl radicals (Eq. (1)) (Panizza and Cerisola, 2009; Isarain-Chavez et al., 2013; Panizza and Martinez-Huitle, 2013; Brillas and Martínez-Huitle, 2015; Martínez-Huitle et al., 2015).

$\mathrm{H}_{2} \mathrm{O} \rightarrow{ }^{\cdot} \mathrm{OH}+\mathrm{e}^{-}+\mathrm{H}^{+}$

These electrogenerated species are primordially physisorbed on diamond surface (surface interacts so weakly with ${ }^{\circ} \mathrm{OH}$ ), playing an important role in the electrochemical conversion/combustion of organic pollutants (Oturan, 2000; Panizza and Cerisola, 2009; Brillas and Martínez-Huitle, 2015; Martínez-Huitle et al., 2015). Also, other reactive oxygen species $\left(\mathrm{H}_{2} \mathrm{O}_{2}\right.$ and $\left.\mathrm{O}_{3}\right)$ and oxidants can be electrochemically produced, such as peroxo-species, when dissolved carbonates, sulfates and phosphates are present in solution (Eqs. (2)-(4)).

$2 \mathrm{SO}_{4}^{2-} \rightarrow \mathrm{S}_{2} \mathrm{O}_{8}^{2-}+2 \mathrm{e}^{-}$

$2 \mathrm{PO}_{4}^{3-} \rightarrow \mathrm{P}_{2} \mathrm{O}_{8}^{4-}+2 \mathrm{e}^{-}$

$2 \mathrm{CO}_{3}^{2-} \rightarrow \mathrm{C}_{2} \mathrm{O}_{6}^{2-}+2 \mathrm{e}^{-}$

Although the applicability of the EO seems feasible due to its environmental compatibility, amenability of automation, high energy efficiency, versatility and safety operating at mild conditions (Polcaro et al., 2004, 2005; Oturan et al.,. 2008; Sanchez-Carretero et al., 2011; Scialdone et al., 2012; Panizza and Martinez-Huitle, 2013); combination of this electrochemical technology with other processes (oxidants production, ultraviolet light (UVC) irradiation or ultrasound (US) irradiation) is becoming the new technological challenge (Polcaro et al., 2009; Scialdone et al., 2009a; Vacca et al., 2011; Wols and Hofman-Caris, 2012; Shih et al., 2014).

In this context, the combination of EO based on diamond conductive anodes with light irradiation has received great interest (Souza et al., 2013a, 2013b) because the combination of these approaches is not looking constantly for heterogeneous photocatalytic processes occurring on the surface of the anode; but in many cases, it is looking for the homogeneous activation of oxidants occurring in the bulk (Alves et al., 2010; Malpass et al., 2010).

Based on the existing literature (Serrano et al., 2002; Cañizares et al., 2005a, 2005b; Sanchez et al., 2013; Velazquez-Pena et al., 2013), peroxo-species $(-\mathrm{O}=\mathrm{O}-$ ) are known to conform a very interesting group of oxidants (Sanchez et al., 2013). However, these peroxo-species are not kinetically rapid when are electrochemically generated and behave as non-selective soft oxidants. Therefore, their activation into more reactive species (peroxo-anion radicals) is necessary (Sires et al., 2014). The production of these radicals can be promoted by using light irradiation (Eqs. (5)-(7)) and by the synergic interactions between the oxidants in the bulk (chemical activation).

$\mathrm{S}_{2} \mathrm{O}_{8}{ }^{2-}+h v \rightarrow 2\left(\mathrm{SO}_{4}^{-}\right)^{\bullet}$

$\mathrm{P}_{2} \mathrm{O}_{8}{ }^{4-}+h v \rightarrow 2\left(\mathrm{PO}_{4}{ }^{2-}\right)^{\bullet}$

$\mathrm{C}_{2} \mathrm{O}_{6}{ }^{2-}+h v \rightarrow 2\left(\mathrm{CO}_{3}^{-}\right)^{\bullet}$

Taking into consideration the above information, this research aims to investigate the improvement on the catalytic effect of peroxodisulfate $\left(\mathrm{S}_{2} \mathrm{O}_{8}^{2-}\right)$ and peroxodiphosphate $\left(\mathrm{P}_{2} \mathrm{O}_{8}^{4-}\right)$ electrochemically generated at diamond electrode (heterogeneous catalytic approach) by activation with light irradiation to produce highly reactive oxidizing species such as sulfate $\left(\mathrm{SO}_{4}^{--}\right)$and phosphate $\left(\mathrm{PO}_{4}^{2-\cdot}\right)$ radicals during the treatment of a model organic compound. The oxidation approaches were also compared with chemical oxidation where the oxidants were initially electrogenerated, and successively, their activation with light irradiation was performed. The mechanisms involved (synergic process (Scialdone, 2009b; Scialdone et al., 2010; de Oliveira, 2012) and/or oxidants activation) and their catalytic effect, on the efficiency during the treatment of synthetic solutions containing Rhodamine $\mathrm{B}(\mathrm{RhB})$, were established, at different oxidative processes. RhB $\left(\mathrm{C}_{28} \mathrm{H}_{31} \mathrm{ClN}_{2} \mathrm{O}_{3}\right)$ was chosen as model organic pollutant because it is widely used in textiles, leathers and food stuffs with high water solubility as well as the neurotoxicity, carcinogenicity, reproductive and developmental toxicity. Adittionally, the chronic toxicity of RhB in human beings and animals have been proven experimentally (Kornbrust and Barfknecht, 1985; IARC, 1987). For this reason, RhB is considered as a persistant organic pollutant (POP).

\section{Material and methods}

\subsection{Chemicals}

High purity reagents were used in this study and supplied by Fluka. Solutions of $\mathrm{RhB}\left(2.09 \times 10^{-4} \mathrm{M}\right)$ were prepared by using $\mathrm{Na}_{2} \mathrm{SO}_{4}$ or $\mathrm{H}_{3} \mathrm{PO}_{4}\left(7.04 \times 10^{-3} \mathrm{M}\right)$ as supporting electrolyte. All aqueous solutions were prepared using Milli-Q water.

\subsection{Analytical procedures}

Color removal was followed by UV-vis spectrophotometric technique using a UV-1603 spectrophotometer Model Shimadzu, at a wavelength of $550 \mathrm{~nm}$. Chemical oxygen demand (COD) was determined by using pre-dosage vials with $2 \mathrm{~mL}$ of sample. Total organic carbon (TOC) was determined with a TOC analysator Multi $\mathrm{N} / \mathrm{C}$ (Analytikjena) by analyzing $10 \mathrm{~mL}$ of each sample.

\subsection{Bulk electrolysis}

Bulk electrochemical experiments were performed by using a flow cell (undivided) with a BDD disc and stainless steel, as anode and cathode, respectively (each one of them with $78 \mathrm{~cm}^{2}$ of geometrical area), under galvanostatic conditions using a power supply. Experiments were carried out at $25^{\circ} \mathrm{C}$ by applying a current density $(j)$ of 15 or $90 \mathrm{~mA} \mathrm{~cm}^{-2}$ to treat $1 \mathrm{~L}$ of $\mathrm{RhB}$ solutions with different supporting electrolytes. 


\subsection{Chemical oxidation tests}

Solutions of oxidants were prepared by electrolyzing a solution of sodium sulfate or phosphoric acid at $90 \mathrm{~mA} \mathrm{~cm}^{-2}$ for $240 \mathrm{~min}$ by irradiating (photoelectrolysis) or not (electrolysis) UV light. Then, the resulting solutions were dosed (in different ratios (\% oxidant solution)) to synthetic wastewater containing RhB to assess the chemical oxidation of this organic compound by the oxidants produced electrochemically. The chemical analysis of UV-visible, TOC and HPLC were performed for all samples. Oxidants concentration was determined by iodometric titration (Dionisio et al., 2018).

\subsection{Light irradiation}

A UV lamp VL-215MC (Vilber Lourmat), $\lambda=254 \mathrm{~nm}$, of intensity of $930 \mu \mathrm{W} \mathrm{cm}{ }^{-2}$ and energy $4.43-6.20 \mathrm{eV}$ was used to irradiate $15 \mathrm{~W}$ directly to the quartz cover of the electrochemical cell (in photoelectrolysis tests) or to the beakers in which the oxidants previously electrogenerated were activated to perform the chemical oxidation tests.

\section{Results and discussion}

Fig. 1 compares the color removal from the RhB solution in sulfate (Fig. 1a) and phosphate (Fig. 1b) as supporting electrolytes by using photolysis, electrolysis and photoelectrolysis. As it can be seen, no significant color removal was achieved by photolysis (fewer than 10\%). This behavior is related to the fragmentation of the chromophore group of few molecules of RhB when UV light is irradiated (Fig. 1). It is confirmed when no current and no light irradiation were applied (no color removal was achieved), indicating that RhB is quite stable organic compound (recalcitrant pollutant), and consequently, its treatment is a priority. Conversely, when a current is applied (15 and $90 \mathrm{~mA} \mathrm{~cm}^{-2}$ ) in the electrochemical cell, significant differences, in terms of color removal, are achieved between electrolysis and light irradiation. These figures are explained in terms of the direct and mediated EO mechanisms during electrolysis of RhB solutions. In direct EO, the organic pollutants are oxidized by direct electron transfer to the electrode surface. Meanwhile, in indirect EO, the heterogeneous production of the oxidants occurs on the anode surface (hydroxyl radicals $\left({ }^{\circ} \mathrm{OH}\right)$, peroxodisulfates $\left(\mathrm{S}_{2} \mathrm{O}_{8}^{2-}\right)$ and peroxophosphates $\left(\mathrm{P}_{2} \mathrm{O}_{8}^{4-}\right)$ ), and subsequently, these oxidants attack the organic pollutants in solution (Labiadh et al., 2016). Another interesting feature is that, when an increase on the applied current density is attained, the discoloration rate is intensified. This indicates that the concentration of strong (hydroxyl radicals $\left({ }^{\circ} \mathrm{OH}\right)$ ) and soft oxidants (peroxodisulfate $\left(\mathrm{S}_{2} \mathrm{O}_{8}^{2-}\right.$, Fig. 1a (Eq. (2))) and peroxophosphates $\left(\mathrm{P}_{2} \mathrm{O}_{8}^{4-}\right.$, Fig. 1b (Eq. (3))) is improved, when the applied current density is increased (Serrano et al., 2002; Cañizares et al., 2008; Weiss et al., 2008). Similar effects were observed during the treatment of different types of wastewaters containing supporting electrolyte salts (Cañizares et al., 2005b, 2009a; Aquino et al., 2012).

It is also interesting to observe from Fig. 1 that, significant differences are attained when the RhB solution is irradiated with UV light during its electrolysis with BDD anode at 15 and $90 \mathrm{~mA} \mathrm{~cm}^{-2}$. Results clearly showed that the color removal efficiency was intensified than the results obtained by photolysis and electrolysis approaches. This improvement is due to the activation of the peroxo oxidants electrogenerated by ligh irradiation, forming sulfate $\left(\mathrm{SO}_{4}^{-}\right)$and phosphate $\left(\mathrm{PO}_{4}^{2-*}\right)$ radicals (Eqs (5) and (6)), which contribute to the decolorisation rate. Additionally, the efficacy of the homogeneous catalytic effect showed by $\mathrm{SO}_{4}^{-}$(Fig. 1a) was more significant than $\mathrm{PO}_{4}^{2-\cdot}$ (Fig. 1b) as well as this intensification is
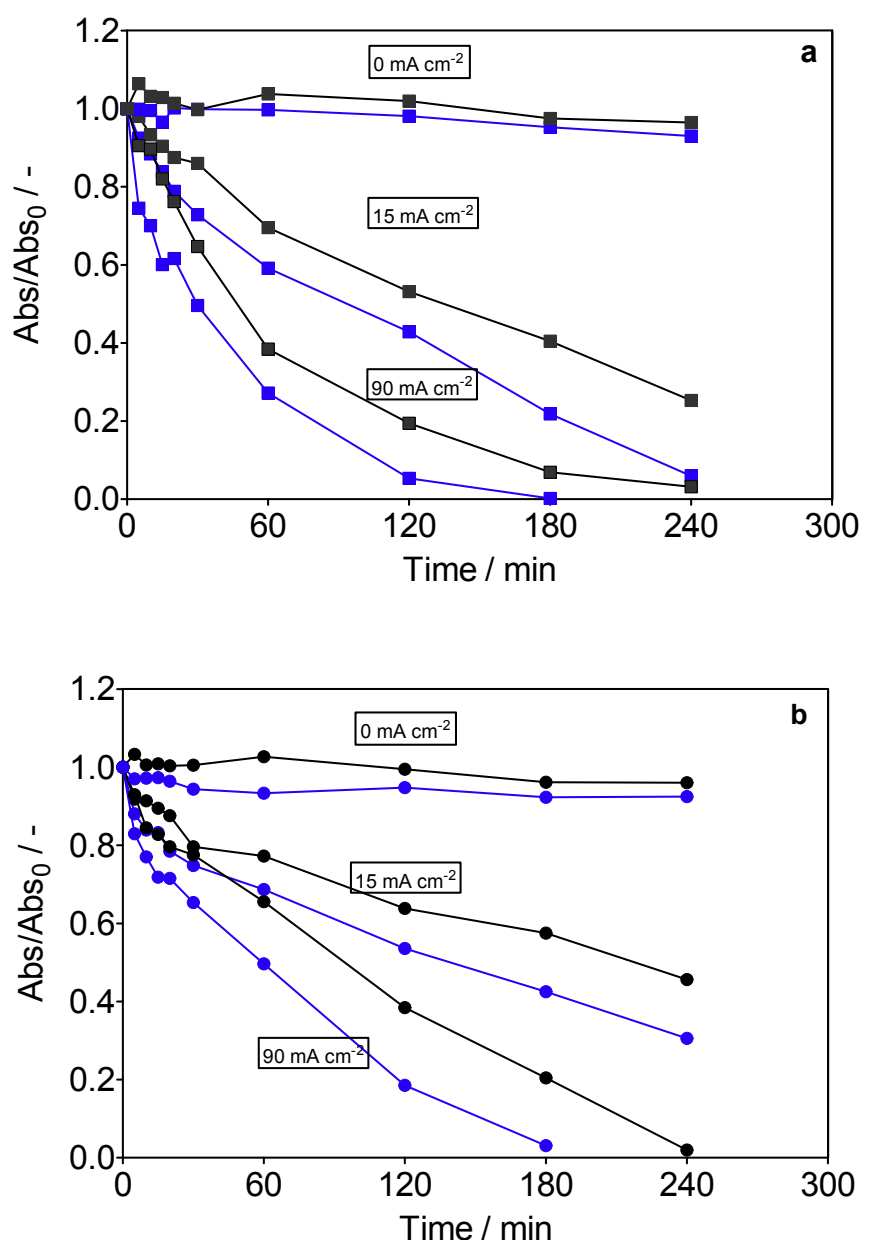

Fig. 1. Removal of color during the photolysis, electrolysis and photoelectrolysis of solutions containing $\mathrm{RhB}$ in a) $\mathrm{Na}_{2} \mathrm{SO}_{4}: 0 \mathrm{~mA} \mathrm{~cm}^{-2}$ for $(\boldsymbol{\square})$ no UV irradiation and ( $\square$ ) with UV irradiation; $15 \mathrm{~mA} \mathrm{~cm}^{-2}$ for (ם) no UV irradiation and (ם) with UV irradiation; $90 \mathrm{~mA} \mathrm{~cm}^{-2}$ for ( $\left.\mathbf{\square}\right)$ no UV irradiation and ( $\left(\mathbf{)}\right.$ with UV irradiation and b) $\mathrm{H}_{3} \mathrm{PO}_{4}$ : $0 \mathrm{~mA} \mathrm{~cm}{ }^{-2}$ for ( $)$ no UV irradiation and ( ) with UV irradiation; $15 \mathrm{~mA} \mathrm{~cm}^{-2}$ for $(\bullet)$ no UV irradiation and (๑) with UV irradiation; $90 \mathrm{~mA} \mathrm{~cm}^{-2}$ for $(\bullet)$ no UV irradiation and (๑) with UV irradiation.

improved when an increase on the applied current denty is attained (Cañizares et al., 2007, 2009b; Rodrigo et al, 2010a, 2010b). Then, an efficient production of peroxo-anion radicals $\left(\mathrm{SO}_{4}^{-}\right.$and $\mathrm{PO}_{4}^{2-\cdot}$ ) is achieved from $\mathrm{S}_{2} \mathrm{O}_{8}^{2-}$ than $\mathrm{P}_{2} \mathrm{O}_{8}^{4-}$ when UV light is irradiated, promoting the fragmentation of chromophore group in the chemical structure of RhB.

The participation of $\mathrm{SO}_{4}^{-}$and $\mathrm{PO}_{4}^{2-\bullet}$ in the degradation of $\mathrm{RhB}$ is clear when the level of degradation and mineralization, in terms of COD and TOC, were determined. Fig. 2 shows the COD and TOC changes, as a function of time, during the electrolysis and photoelectrolysis of RhB solution containing with sulfate as electrolyte by applying 15 and $90 \mathrm{~mA} \mathrm{~cm}^{-2}$. In the case of electrolysis, considerable organic removal (Fig. 2a) and mineralization (Fig. 2b) efficiencies were achieved, at both current densities (60\% of COD and $49 \%$ of TOC at $15 \mathrm{~mA} \mathrm{~cm}^{-2}$ and $80 \%$ of COD and $75 \%$ of TOC at $90 \mathrm{~mA} \mathrm{~cm}^{-2}$ ). Conversely, a significant intensification on the degradation (75\% and $92 \%$ by applying 15 and $90 \mathrm{~mA} \mathrm{~cm}^{-2}$, respectively) and mineralization (70\% and $95 \%$ by applying 15 and $90 \mathrm{~mA} \mathrm{~cm}^{-2}$, respectively) efficiencies of RhB was attained when photoelectrolysis approach was used. This effect is in agreement with the results achieved during the elimination of color (see, Fig. 1).

In the case of electrolysis, mass transport limitations affect in 

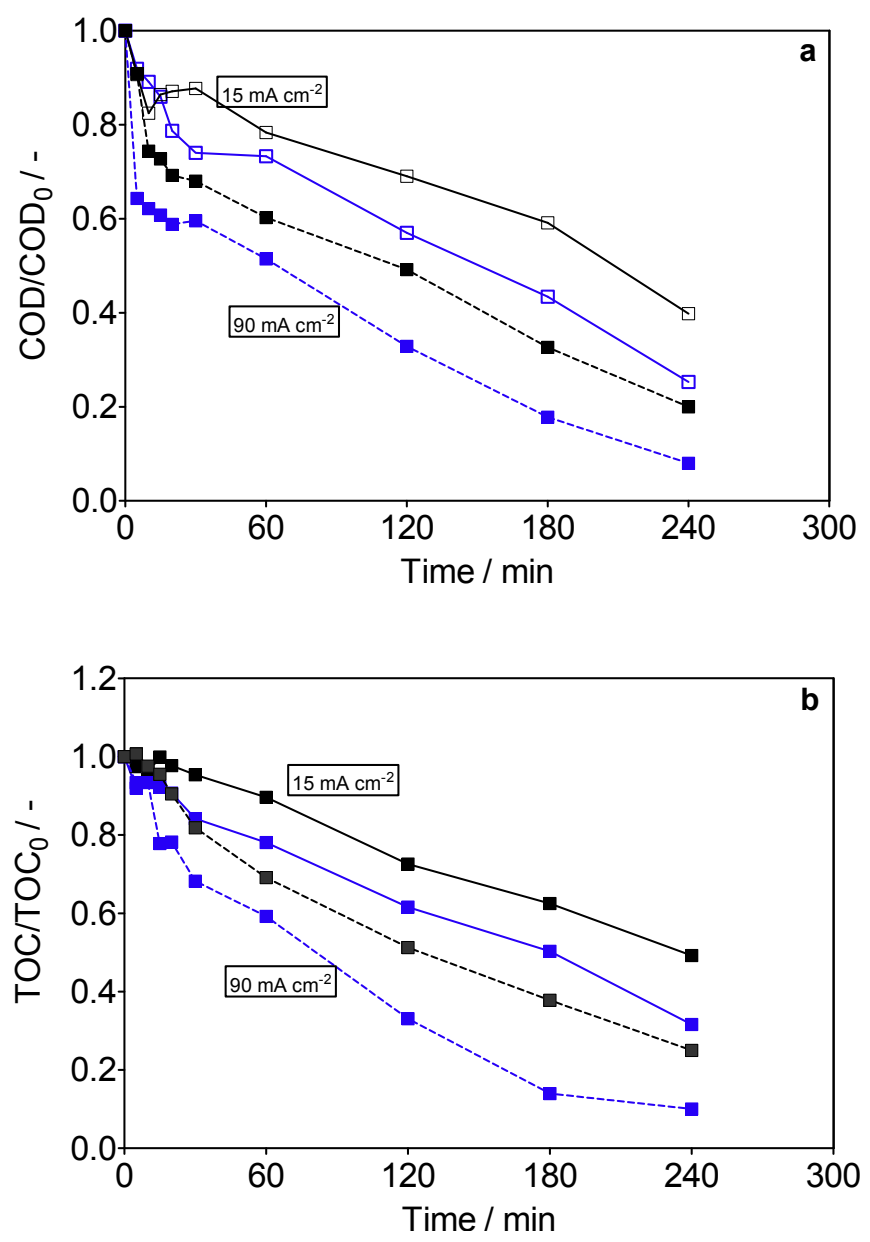

Fig. 2. Oxidation (in terms of normalized COD removal) and mineralization (in terms of normalized TOC removal) during the electrolysis and photoelectrolysis of solutions containing $\mathrm{RhB}$ in $\mathrm{Na}_{2} \mathrm{SO}_{4}: 15 \mathrm{~mA} \mathrm{~cm}^{-2}$ for $(\square)$ no UV irradiation and ( $\square$ ) with UV irradiation; $90 \mathrm{~mA} \mathrm{~cm}^{-2}$ for ( $\left.\boldsymbol{\square}\right)$ no UV irradiation and (ם) UV irradiation.

the effectiveness of the process. At low current densities $\left(15 \mathrm{~mA} \mathrm{~cm}^{-2}\right)$, the concentration of pollutant in solution as well as the lower production of oxidants (hydroxyl radicals $\left({ }^{\circ} \mathrm{OH}\right)$ and peroxodisulfates $\left(\mathrm{S}_{2} \mathrm{O}_{8}^{2-}\right)$ ) limit the homogenous catalytic effect in the solution, achieving lower COD and TOC removal efficiencies. Conversely, an efficient production of oxidants is attained (Fig. 2) at $90 \mathrm{~mA} \mathrm{~cm}^{-2}$, enhancing the homogeneous catalytic reactions and consequently, increasing the degradation (changes in the COD, see Fig. 2a) and the mineralization (changes in the TOC, see Fig. 2b) efficiencies. On the contrary, the improvement on the catalytic effect of $\mathrm{S}_{2} \mathrm{O}_{8}^{2-}$ electrochemically generated at diamond electrode is a consequence of its activation to form $\mathrm{SO}_{4}^{-}$radicals by light irradiation when photoelectrolysis approach was used. Despite the mass transfer limitations affect the process; this effect becomes less important because the non-selective soft oxidants $\left(\mathrm{S}_{2} \mathrm{O}_{8}^{2-}\right)$ are activated to stronger oxidant species $\left(\mathrm{SO}_{4}^{-}\right)$in the bulk of the solution, increasing the homogenous catalytic reactions.

Fig. 3 shows the COD and TOC changes observed, as a function of time, during the electrolysis and photoelectrolysis of RhB in phosphate solution by applying 15 and $90 \mathrm{~mA} \mathrm{~cm}^{-2}$. The same qualitative behavior observed at sulfate supporting electrolyte can be observed in phosphate medium. Photoelectrolysis treatment is more effective to degrade and mineralize the model organic pollutant than electrolysis. The COD and TOC removal efficiencies were improved when an increase on the current density was achieved; and the effect of light irradiation (and hence of the activation
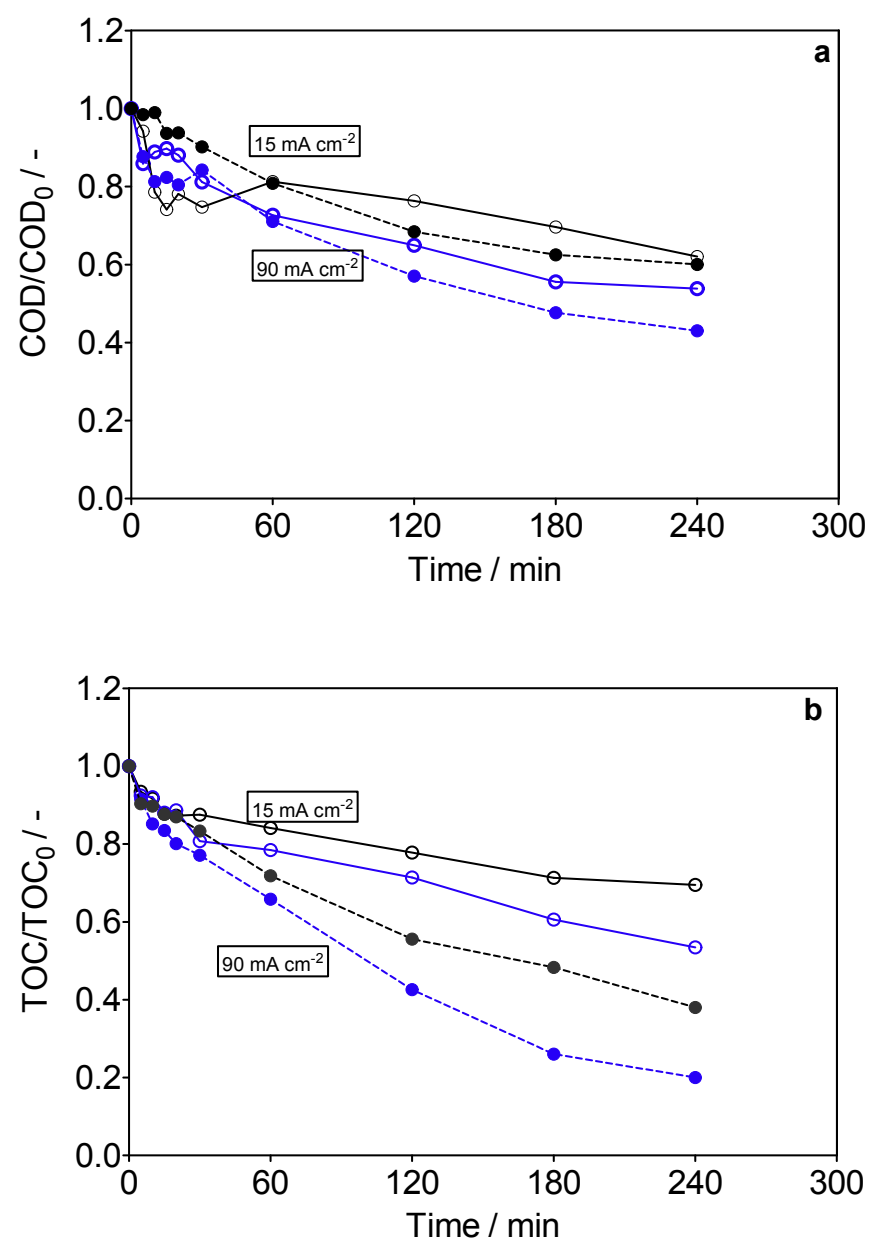

Fig. 3. Oxidation (in terms of normalized COD removal) and mineralization (in terms of normalized TOC removal) during the electrolysis and photoelectrolysis of solutions containing $\mathrm{RhB}$ in $\mathrm{H}_{3} \mathrm{PO}_{4}$ : $15 \mathrm{mAcm}^{-2}$ for $(\mathrm{O})$ no UV irradiation and $(\mathrm{O})$ with UV irradiation; $90 \mathrm{~mA} \mathrm{~cm}^{-2}$ for (๑) no UV irradiation and (๑) with UV irradiation.

of oxidants, $\mathrm{P}_{2} \mathrm{O}_{8}^{4-}$ to form $\mathrm{PO}_{4}^{2-\cdot}$ ) was also clearly observed, especially during the RhB mineralization (Fig. 3b). Nevertheless, the decontamination enhancement showed by photoelectrolysis in phosphate medium was not superior than the figures achieved in sulfate solution. For example, at $90 \mathrm{~mA} \mathrm{~cm}^{-2}$ in phosphate medium, $38 \%$ and $63 \%$ of COD and TOC removals were reached by electrolysis, while $60 \%$ and $85 \%$ of COD and TOC removals were achieved by photoelectrolysis after $240 \mathrm{~min}$ of treatment. Meanwhile, at $90 \mathrm{~mA} \mathrm{~cm}^{-2}$ in sulfate medium, $80 \%$ and $75 \%$ of COD and TOC removals were reached by electrolysis, while $92 \%$ and $95 \%$ of COD and TOC removals were achieved. These results clearly indicate that the sulfate species $\left(\mathrm{S}_{2} \mathrm{O}_{8}^{2-}\right.$ and $\left.\mathrm{SO}_{4}^{-}\right)$are more efficient in the mineralization of $\mathrm{RhB}$ pollutant, being that the oxidants activation played a key role in the homogenous catalytic reactions (Elahmadi et al., 2009; dos Santos et al., 2014).

In order to understand the activation of $\mathrm{S}_{2} \mathrm{O}_{8}^{2-}$ and $\mathrm{P}_{2} \mathrm{O}_{8}^{4-}$ by irradiating UV light, a new set of experiments was performed. The electrolytic production of $\mathrm{S}_{2} \mathrm{O}_{8}^{2-}$ and $\mathrm{P}_{2} \mathrm{O}_{8}^{4-}$ was performed in absence of RhB. The liquid electrolyzed was obtained from synthetic solutions containing the same concentrations of sulfate or phosphate reported in Figs. 1-3. After that, the resulting solution was used to carried out the chemical oxidation tests, adding a wellknown volume in different RhB solutions, which allow to test different oxidant ratios.

Fig. 4 shows the concentration of oxidants electrochemically 
generated in absence of organic matter when UV light is irradiated (photoelectrolysis) or not (electrolysis). As it can be observed, the production of oxidants is rapidly achieved at both sulfate and phosphate solutions, after $60 \mathrm{~min}$. The plateau reached, in all cases, is the consequence of the equilibrium between the electrolytic production and the decomposition of the oxidants (Cañizares et al., 2005a). By using phosphate as supporting electrolyte, photoelectrolysis showed a slight enhancement on the production of oxidants when compared to the electrolysis approach. This behavior is due to the recombination of the radicals produced by light irradiation. Meanwhile, the formation of oxidants in sulfate medium was significantly improved when photoelectrolysis was employed (see Fig. 4, blue squares) respect to the electrolysis.

When the solutions of oxidants electrochemically produced by using sulfate or phosphate medium (at $90 \mathrm{~mA} \mathrm{~cm}^{-2}$ for $240 \mathrm{~min}$ by irradiating (photoelectrolysis) or not (electrolysis) UV light) were added to the solution containing with $\mathrm{RhB}$, oxidants are consumed. As it can be seen in Fig. 5, the higher the concentration of oxidant added, the higher is the concentration of oxidant removed because it participates in the oxidation of $\mathrm{RhB}$ and its byproducts. No great differences are observed when the oxidants were UV light activated. This means that the oxidants (peroxo-species and peroxoanion radicals) promote the oxidation of organic matter but the UV light irradiation has not a clear effect out of an electrolytic environment. This behavior is clearly observed when the trends on the color elimination (Fig. 6a) as well as COD (Fig. 6b) and TOC (Fig. 6c) decays were plotted. Although the amount of oxidants solution is increased, activated by UV light irradiation or not, no improvements in the discoloration, degradation and mineralization were observed. When the solutions of oxidants, previously electrogenerated, were added to the RhB effluents, it seems clearly that the oxidants interact chemically with $\mathrm{RhB}$, but not a clear influence of light irradiation to activate $\mathrm{S}_{2} \mathrm{O}_{8}^{2-}$ and $\mathrm{P}_{2} \mathrm{O}_{8}^{4-}$ can be drawn.

It is important to remark that, the formation of other oxidants is feasible due to the heterogeneous reactions at BDD surface (Marselli et al., 2003; Groenen-Serrano et al., 2013, Sirés et al., 2014) during electrolysis and photoelectrolysis processes, such as hydroxyl radicals, hydrogen peroxide and ozone, as shown in Eqs. 9 and 10.

$\mathrm{H}_{2} \mathrm{O} \rightarrow \cdot \mathrm{OH}+\mathrm{H}^{+}+\mathrm{e}^{-}$

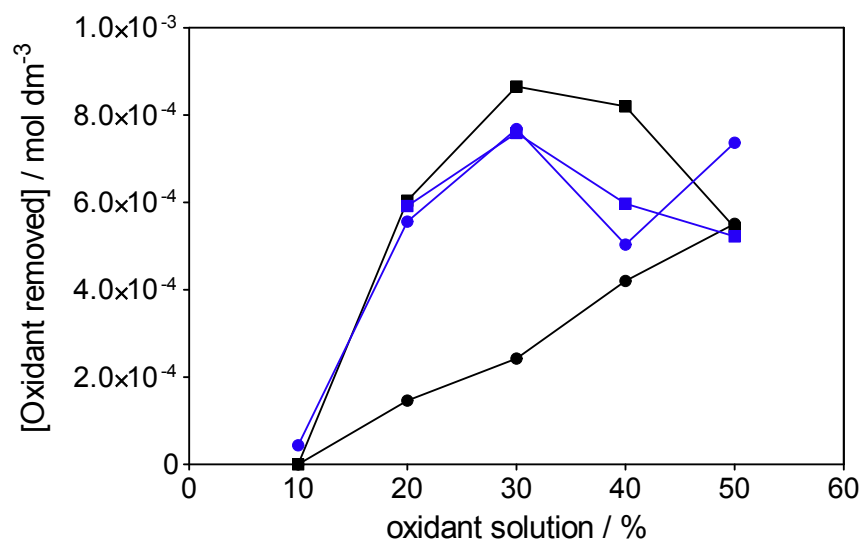

Fig. 5. Oxidant consumed (initial - final) in chemical oxidation tests of RhB with the oxidant produced electrolytically from $\mathrm{Na}_{2} \mathrm{SO}_{4}$ for $(\boldsymbol{\square})$ no UV irradiation and with ( UV irradiation; $\mathrm{H}_{3} \mathrm{PO}_{4}$ for $(\bullet)$ no UV irradiation and with (๑) UV Irradiation.

$2^{\cdot} \mathrm{OH} \rightarrow \mathrm{H}_{2} \mathrm{O}_{2}$

$\mathrm{O}_{2}+2 \cdot \mathrm{OH} \rightarrow \mathrm{O}_{3}+\mathrm{H}_{2} \mathrm{O}$

At the same time, ozone and hydrogen pexoxide are affected by UV light irradiation and they can regenerate the hydroxyl radical in the bulk, as shown in Eqs. (11) and (12) (Oturan et al., 2001; Brillas et al., 2009; Sires et al., 2014).

$\mathrm{H}_{2} \mathrm{O}_{2}+h v \rightarrow 2^{\circ} \mathrm{OH}$

$\mathrm{H}_{2} \mathrm{O}+\mathrm{O}_{3}+h v \rightarrow 2^{\bullet} \mathrm{OH}+\mathrm{O}_{2}$

Hydrogen peroxide can also react with ozone, $\mathrm{S}_{2} \mathrm{O}_{8}^{2-}$ and $\mathrm{P}_{2} \mathrm{O}_{8}^{4-}$ (Eqs. (13)-(15)), and their effect could be magnified by the light irradiation (Sires et al., 2014).

$\mathrm{H}_{2} \mathrm{O}_{2}+2 \mathrm{O}_{3} \rightarrow 2^{\circ} \mathrm{OH}+3 \mathrm{O}_{2}$

$\mathrm{P}_{2} \mathrm{O}_{8}{ }^{4-}+\mathrm{H}_{2} \mathrm{O}_{2} \rightarrow 2 \mathrm{PO}_{4}^{2-\bullet}+2 \cdot \mathrm{OH}$

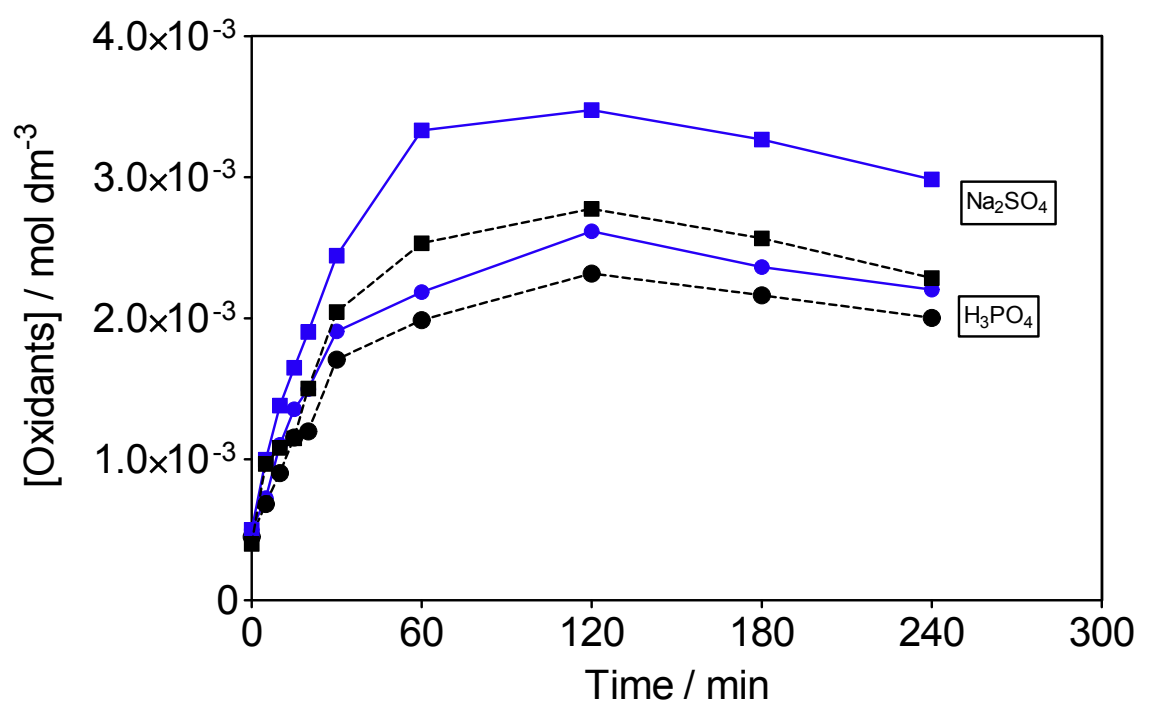

Fig. 4. Production of oxidants by electrolysis with conductive-diamond of solutions containing $\mathrm{Na}_{2} \mathrm{SO}_{4}$ for ( $\boldsymbol{\square}$ ) no UV irradiation and with ( irradiation and with () UV irradiation. 

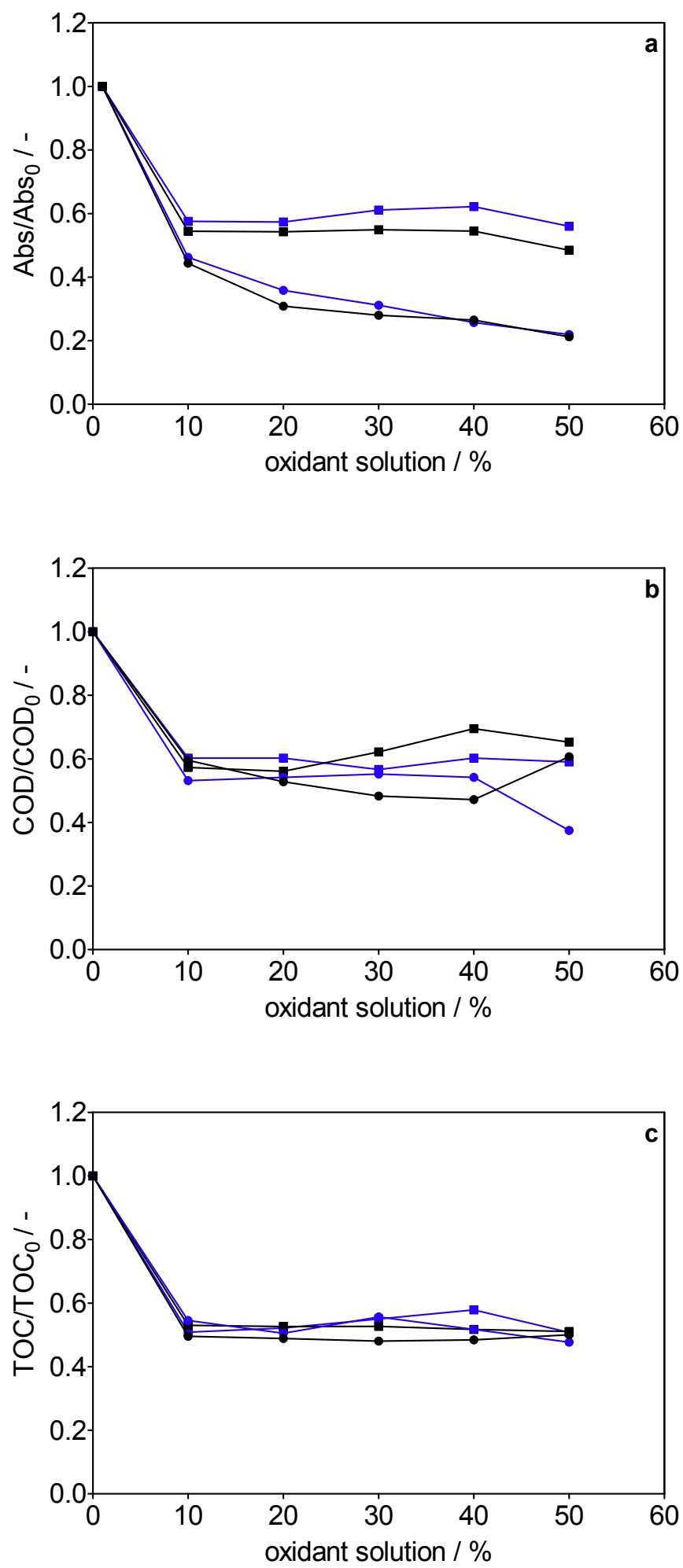

Fig. 6. Changes in the (a) color, (b) COD and (c) TOC during the chemical oxidation of dye solutions with different \% of oxidant solution produced by electrolyzing $\mathrm{H}_{3} \mathrm{PO}_{4}$ for

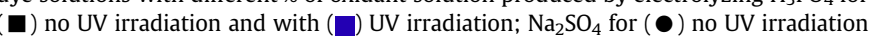
and (0) with UV irradiation.

$\mathrm{S}_{2} \mathrm{O}_{8}{ }^{2-}+\mathrm{H}_{2} \mathrm{O}_{2} \rightarrow 2 \mathrm{SO}_{4}^{-\bullet}+2 \cdot \mathrm{OH}$

Then, a significant complexity in the system is expected during the electrochemical generation of oxidants by UV light irradiation or not, which can affect the action of these oxidants when are introduced in the RhB solutions. Even when, the results of the chemical oxidation tests are positive to eliminate RhB from solution at different oxidant dosages (Fig. 6), the in situ production of oxidants as well as the UV light activation play a key role, in terms of the homogeneous catalytic effect (Figs. 1-3), during photoelectrolysis approach. The most important role is associated to the synergic interactions achieved during the constant exposure to the UV irradiation.

\section{Conclusions}

From this work the following conclusions can be drawn:

Light irradiation promotes an enhancement on the discoloration, degradation and mineralization of $\mathrm{RhB}$ solution during the electrolysis by using phosphate or sulfate as supporting electrolytes. This effect is greater at high current densities.

$\mathrm{RhB}$ is efficiently oxidized and mineralized by peroxo-species and peroxo-anion radicals produced photoelectocatalytically; however, the effect observed when sulfate is used as supporting electrolyte is more aggressive than phosphate.

Synergic effects occur during the photoelectrolysis are not reproduced, if the process is divided into two separated stages (oxidants production by electrolysis or photoelectrolysis by using sulfate and phosphate solutions is performed, and after that, the solutions are introduced in the RhB effluent to promote chemical oxidation); indicating that the production of oxidants separately (which can be optimized) and their application to the treatment of the wastewater in a later chemical oxidation, is not a very interesting choice because some important mechanisms are excluded than when the process is performed in one-step.

\section{Acknowledgements}

D.M.A. acknowledges the CAPES for PhD fellowship and CNPq for the fellowship given for "doutorado sanduiche" under "Ciências sem Fronteiras" program to develop the experimental research at the UCLM-Spain. Financial support of the Spanish government and EU through project FEDER 2007-2013 PP201010 (Planta Piloto de Estación de Regeneración de Aguas Depuradas) is gratefully acknowledged. Financial supports from National Council for Scientific and Technological Development (CNPq - 465571/2014-0; CNPq - 446846/2014-7 and CNPq - 401519/2014-7) and FAPESP (2014/50945-4) are gratefully acknowledged.

\section{References}

Alves, P.A., Malpass, G.R.P., Johansen, H.D., Azevedo, E.B., Gomes, L.M., Vilela, W.F.D., Motheo, A.J., 2010. Photo-assisted electrochemical degradation of real textile wastewater. Water Sci. Technol. 61, 491-498.

Aquino, J.M., Rodrigo, M.A., Rocha-Filho, R.C., Saez, C., Cañizares, P., 2012. Influence of the supporting electrolyte on the electrolyses of dyes with conductivediamond anodes. Chem. Eng. J. 184, 221-227.

Bebelis, S., Bouzek, K., Cornell, A., Ferreira, M.G.S., Kelsall, G.H., Lapicque, F., de Leon, C.P., Rodrigo, M.A., Walsh, F.C., 2013. Highlights during the development of electrochemical engineering. Chem. Eng. Res. Des. 91, 1998-2020.

Borras, N., Arias, C., Oliver, R., Brillas, E., 2013. Anodic oxidation, electro-Fenton and photoelectro-Fenton degradation of cyanazine using a boron-doped diamond anode and an oxygen-diffusion cathode. J. Electroanal. Chem. 689, 158-167.

Brillas, E. Martinez-Huitle, C.A., 2015. Decontamination of wastewaters containing synthetic organic dyes by electrochemical methods. An updated Review. Appl. Catal. B: Environ. 166-167, 603-643.

Brillas, E., Sires, I., Oturan, M.A., 2009. Electro-Fenton process and related electrochemical technologies based on Fenton's reaction chemistry. Chem. Rev. 109, 6570-6631.

Cañizares, P., Paz, R., Saez, C., Rodrigo, M.A., 2009b. Costs of the electrochemical oxidation of wastewaters: a comparison with ozonation and Fenton oxidation processes. J. Environ. Manag. 90, 410-420.

Cañizares, P., Hernandez, M., Rodrigo, M.A., Saez, C., Barrera, C.E., Roa, G., 2009a. Electrooxidation of brown-colored molasses wastewater. Effect of the 
electrolyte salt on the process efficiency. Ind. Eng. Chem. Res. 48, 1298-1301.

Cañizares, P., Larrondo, F., Lobato, J., Rodrigo, M., Saez, C., 2005a. Electrochemical synthesis of peroxodiphosphate using boron-doped diamond anodes. J. Electrochem. Soc. 152, D191-D196.

Cañizares, P., Lobato, J., Paz, R., Rodrigo, M., Saez, C., 2005b. Electrochemical oxidation of phenolic wastes with boron-doped diamond anodes. Water Res. 39, 2687-2703.

Cañizares, P., Saez, C., Lobato, J., Paz, R., Rodrigo, M.A., 2007. Effect of the operating conditions on the oxidation mechanisms in conductive-diamond electrolyses. J. Electrochem. Soc. 154, E37-E44.

Cañizares, P., Saez, C., Sanchez-Carretero, A., Rodrigo, M.A., 2008. Influence of the characteristics of $\mathrm{p}-\mathrm{Si}$ BDD anodes on the efficiency of peroxodiphosphate electrosynthesis process. Electrochem. Commun. 10, 602-606.

de Oliveira, G.R., Costa de Araujo, C.K., Martinez-Huitle, C.A., da Silva, D.R., 2012. Complementary mechanism model for the electrochemical mineralization. Org. Chem. 16, 1957-1959.

Dionisio, D., Motheo, A.J., Sáez, C., Rodrigo, M.A., 2018. Effect of the electrolyte on the electrolysis and photoelectrolysis of synthetic methyl paraben polluted wastewater. Separ. Purif. Technol. https://doi.org/10.1016/j.seppur.2018.03.009.

dos Santos, E.V., Sena, S.F.M., da Silva, D.R. Ferro, S., De Battisti, A., MartínezHuitle, C.A., 2014. Scale-up of electrochemical oxidation system for treatment of produced water generated by Brazilian petrochemical industry. Environ. Sci. Pollut. Res. 21, 8466-8475.

Elahmadi, M.F., Bensalah, N., Gadri, A., 2009. Treatment of aqueous wastes contaminated with Congo Red dye by electrochemical oxidation and ozonation processes. J. Hazard Mater. 168, 1163-1169.

Groenen-Serrano, K., Weiss-Hortala, E., Savall, A., Spiteri, P., 2013. Role of hydroxyl radicals during the competitive electrooxidation of organic compounds on a boron-doped diamond anode. Electrocatalysis 4, 346-352.

IARC, 1987. Overall Evaluations of Carcinogenicity: an Updating of IARC Monographs vol. 1-42 (Suppl. 7)

Isarain-Chavez, E., de la Rosa, C., Martinez-Huitle, C.A., Peralta-Hernandez, J.M., 2013. On-site hydrogen peroxide production at pilot flow plant: application to electro-Fenton process. Int. J. Electrochem. Sci. 8, 3084-3094.

Kornbrust, D., Barfknecht, T., 1985. Testing of 24 food, drug, cosmetic, and fabric dyes in the in vitro and the in vivo/in vitro rat hepatocyte primary culture/DNA repair assays. Environ. Mutagen. 7, 101-120.

Labiadh, L., Barbucci, A., Carpanese, M.P., Gadri, A., Panizza, M., 2016. Comparative depollution of methyl orange aqueous solutions by electrochemical incineration using TiRuSnO2, BDD and PbO2 as high oxidation power anodes. J. Electroanal. Chem. 766, 94-99.

Malpass, G.R.P., Miwa, D.W., Machado, S.A.S., Motheo, A.J., 2010. SnO2-based materials for pesticide degradation. J. Hazard Mater. 180, 145-151.

Marselli, B., Garcia-Gomez, J., Michaud, P.A., Rodrigo, M.A., Comninellis, C., 2003. Electrogeneration of hydroxyl radicals on boron-doped diamond electrodes. J. Electrochem. Soc. 150, D79-D83.

Martíne-Huitle, C.A., Rodrigo, M.A., Sires, I., Scialdone, O., 2015. Single and coupled electrochemical processes and reactors for the abatement of organic water pollutants: a critical review. Chem. Rev. 115, 13362-13407.

Martinez-Huitle, C.A., Ferro, S., 2006. Electrochemical oxidation of organic pollutants for the wastewater treatment: direct and indirect processes. Chem. Soc. Rev. 35, 1324-1340.

Oturan, M.A., Sires, I., Oturan, N., Perocheau, S., Laborde, J.-L., Trevin, S., 2008. Sonoelectro-Fenton process: a novel hybrid technique for the destruction of organic pollutants in water. J. Electroanal. Chem. 624, 329-332.

Oturan, M.A., 2000. An ecologically effective water treatment technique using electrochemically generated hydroxyl radicals for in situ destruction of organic pollutants: application to herbicide 2,4-D. J. Appl. Electrochem. 30, 475-482.

Oturan, M.A., Oturan, N., Lahitte, C., Trevin, S., 2001. Production of hydroxyl radicals by electrochemically assisted Fenton's reagent. Application to the mineralization of an organic micropollutant, pentachlorophenol. J. Electroanal. Chem. 507, 96-102.

Panizza, M., Cerisola, G., 2005. Application of diamond electrodes to electrochemical processes. Electrochim. Acta 51, 191-199.

Panizza, M., Cerisola, G., 2009. Direct and mediated anodic oxidation of organic pollutants. Chem. Rev. 109, 6541-6569.

Panizza, M., Martinez-Huitle, C.A., 2013. Role of electrode materials for the anodic oxidation of a real landfill leachate-comparison between Ti-Ru-Sn ternary oxide. PbO2. Boron-doped Diamond Anode Chemosphere 90, 1455-1460.

Polcaro, A.M., Mascia, M., Palmas, S., Vacca, A., 2004. Electrochemical degradation of diuron and dichloroaniline at BDD electrode. Electrochim. Acta 49, 649-656.

Polcaro, A.M., Vacca, A., Mascia, M., Palmas, S., 2005. Oxidation at boron doped diamond electrodes: an effective method to mineralise triazines. Electrochim. Acta 50, 1841-184.

Polcaro, A.M., Vacca, A., Mascia, M., Palmas, S., Ruiz, J.R., 2009. Electrochemical treatment of waters with BDD anodes: kinetics of the reactions involving chlorides. J. Appl. Electrochem. 39, 2083-2092.

Rodrigo, M.A., Cañizares, P., Buitron, C., Saez, C., 2010a. Electrochemical technologies for the regeneration of urban wastewaters. Electrochim. Acta 55, 8160-8164.

Rodrigo, M.A., Cañizares, P., Sanchez-Carretero, A., Saez, C., 2010b. Use of conductive-diamond electrochemical oxidation for wastewater treatment Catal. Today. 151, 173-177.

Rodrigo, M.A., Michaud, P.A., Duo, I., Panizza, M., Cerisola, G., Comninellis, C., 2001 Oxidation of 4-chlorophenol at boron-doped diamond electrodes for wastewater treatment. J. Electrochem. Soc. 148, D60-D64.

Sanchez, A., Llanos, J., Saez, C., Cañizares, P., Rodrigo, M.A., 2013. On the applications of peroxodiphosphate produced by BDD-electrolyses. Chem. Eng. J. 233, 8-13.

Sanchez-Carretero, A., Sáez, C., Cañizares, P., Rodrigo, M.A., 2011. Production of strong oxidizing substances with BDD anodes. In: Brillas, E., MartinezHuitle, C.A. (Eds.), Synthetic Diamond Films: Preparation, Electrochemistry, Characterization, and Applications. Wiley, New York (Chapter 12).

Scialdone, O., 2009. Electrochemical characterizations on MnO2 supercapacitors with potassium polyacrylate and potassium polyacrylate-co-polyacrylamide gel polymer electrolytes. Electrochim. Acta 54, 6140-6147.

Scialdone, O., Galia, A., Randazzo, S., 2012. Electrochemical treatment of aqueous solutions containing one or many organic pollutants at boron doped diamond anodes. Theoretical modeling and experimental data. Chem. Eng. J. 183, $124-134$.

Scialdone, O., Guarisco, C., Galia, A., Filardo, G., Silvestri, G., Amatore, C., Sella, C. Thouin, L., 2010. Anodic abatement of organic pollutants in water in micro reactors. J. Electroanal. Chem. 638, 293-296.

Scialdone, O., Randazzo, S., Galia, A., Silvestri, G., 2009. Electrochemical oxidation of organics in water: role of operative parameters in the absence and in the presence of $\mathrm{NaCl}$. Water Res. 43, 2260-2272.

Serrano, K. Michaud, P.A., Comninellis, C., Savall, A., 2002. Electrochemical preparation of peroxodisulfuric acid using boron-doped diamond thin film electrodes. Electrochim. Acta 48, 431-436.

Shih, Y.J., Chen, K.H., Huang, Y.H., 2014. Mineralization of organic acids by the photo-electrochemical process in the presence of chloride ions. J. Taiwan Inst. Chem. Eng. 45, 962-966.

Sires, I., Brillas, E., 2012. Remediation of water pollution caused by pharmaceutical residues based on electrochemical separation and degradation technologies: a review. Environ. Int. 40, 212-229.

Sirés, I., Brillas, E., Oturan, M.A., Rodrigo, M.A., Panizza, M., 2014. Electrochemical advanced oxidation processes: today and tomorrow. A review Environ. Sci. Pollut. Res. 21, 8336-8367.

Souza, F.L., Saez, C., Cañizares, P., Motheo, A.J., Rodrigo, M.A., 2013a. Sonoelectrolysis of wastewaters polluted with dimethyl phthalate. Ind. Eng. Chem. Res. 52 9674-9682.

Souza, F.L., Sáez, C., Cañizares, P., Motheo, A.J., Rodrigo, M.A., 2013b. Coupling photo and sono technologies to improve efficiencies in conductive diamond electrochemical oxidation. Appl. Catal. B Environ. 144, 121-128.

Vacca, A., Mascia, M., Palmas, S., Da Pozzo, A., 2011. Electrochemical treatment of water containing chlorides under non-ideal flow conditions with BDD anodes. J. Appl. Electrochem. 41, 1087-1097.

Velazquez-Pena, S., Saez, C., Cañizares, P., Linares-Hernandez, I., MartinezMiranda, V., Barrera-Diaz, C., Rodrigo, M.A., 2013. Production of oxidants via electrolysis of carbonate solutions with conductive-diamond anodes. Chem. Eng. J. 230, 272-278.

Weiss, E., Saez, C., Groenen-Serrano, K., Cañizares, P., Savall, A., Rodrigo, M.A., 2008 Electrochemical synthesis of peroxomonophosphate using boron-doped diamond anodes. J. Appl. Electrochem. 38, 93-100.

Wols, B.A., Hofman-Caris, C.H.M., 2012. Review of photochemical reaction constants of organic micropollutants required for UV advanced oxidation processes in water. Water Res. 46, 2815-2827. 